\title{
Returns on ADRs and Arbitrage in Emerging Markets
}

\author{
by \\ Ramon Rabinovitch * \\ Ana Cristina Silva** \\ Raul Susmel*
}

April 2003

\begin{abstract}
In this paper we compare the distributions of ADR returns and the returns of the locally traded shares between Chile and Argentina. This comparison is interesting because both countries are emerging economies with a similar free market orientation and the trading hours in both countries virtually coincide with the trading hours in New York. Argentina and Chile differ, however, in two important aspects: During our sample period, (1) The Argentinean market was completely under a fixed-exchange rate system, while Chile maintained a flexible exchange rate regime and (2) Argentina did not impose any restrictions on foreign investments, while Chile did. We find that the return distributions of the Chilean ADRs are significantly different from the distributions of the returns on the respective underlying Chilean shares. While the mean returns are the same, the return's standard deviations are significantly different. In contrast, the hypothesis that the distributions of the returns on the Argentinean ADRs and the returns on their respective underlying shares are the same cannot be rejected. We then use a threshold model to estimate the transaction costs of trading the ADRs and the locally traded shares. We find that the transaction costs that must be added to the returns spread before arbitrage is possible were between 100 and 200 basis points for Chilean ADRs. It was between 66 to 165 basis points for the Argentinean ADRs. The daily return spread reversion caused by arbitrage activities was estimated to be around 30\% for Chilean ADRs and $40 \%$ for Argentinean ADRs. Finally, we cannot reject the hypothesis that low liquidity was a major factor in the cost difference between the two countries.
\end{abstract}

JEL Classification: F3, G1

* Department of Finance, Bauer College of Business, The University of Houston, Houston TX 77204-6021; ramon@uh.edu; rsusmel@uh.edu, respectively.

** Department of Finance, Universidad Adolfo Ibañez, Santiago, Chile. ansilva@uai.cl.

Acknowledgements: We want to thank Nuria Susmel and Gonzalo Chavez for their help in gathering the data set for this paper. 


\section{Introduction}

Over the last three decades many $\infty$ untries have opened their physical and financial markets to foreign investment. This process, labeled in the literature the process of markets globalization, included the easing of various markets restrictions on capital flows from one country to another. This period has witnessed a remarkable growth of the market for American Depository Receipts (ADRs). ADRs are negotiable certificates traded in the U.S. financial markets; they represent the shares of foreign country firms. American commercial banks serve as the depository units for the ADRs. Thus, although trading ADRs in the U.S. is U.S. dollar denominated, it should be equivalent to trading the foreign firms' shares without actually trading them in their respective local markets.

The market for ADRs has developed for various reasons most of which are analyzed in the literature. Value maximization, diversification, investor recognition and overcoming market segmentation, to name a few. Price and return reaction to cross market listing, possible arbitrage opportunities and the difference between ADR returns and the returns on their local counterpart shares are some of the issues raised by many researchers. For an excellent review of this growing body of literature see Karolyi (1998).

Most studies on the benefits of cross listing have found a positive stock price reaction as well as a decline in the cost of capital. See Alexander, Eun and Janakiramanan (1987), Domowitz, Glen and Madhavan (1997a), Miller (1998), Jayaraman, Shastri and Tandon (1998) and Forester and Karolyi (1999). Officer and Hoffmeister (1987) and Wahab and Khandwala (1993) found that ADRs present investors with an excellent diversification opportunity. Moreover, in the absence of direct or indirect trading barriers, there should not exist significant differences between the return distribution of locally traded shares and that of the U.S. traded ADRs. That is, ADRs and their underlying shares are expected to be perfect substitutes and no 
arbitrage opportunities should be present. Studies by Maldonado and Saunders (1983), Kato, Linn and Schallheim (1991), Park and Tavakkol (1994), Miller and Morey (1996) and Karolyi and Stulz (1996) concluded that ADRs do not present investors with any arbitrage opportunities. The only study that did find some arbitrage opportunities, however, is by Wahab, Lashgari and Cohn (1992).

Many researchers write about the issue of international barriers to trading, investments and cash flows movements. Stulz (1981) develops a model of investment with international trading barriers. Eun and Janakiramanan (1986) describe many of the barriers that existed at that time. More recently, Stulz and Wasserfallen (1995) analyze a case of market segmentation in Switzerland, Bekaert and Harvey (1995) also present a model of partial integration, where integration is time-varying, and Domowitz, Glen and Madhavan (1997b) develop a model of market segmentation based on cash flows restrictions.

On theoretical ground, other possible sources of differences between the return on locally traded shares and the ADR returns are transaction costs, the distribution of the foreign exchange rate between the U.S. and the firm's country, lead - lag time between the U.S. ADRs' markets and the local markets trading hours and liquidity.

First, if transaction costs in the U.S. market are lower than those in the local market it is possible that returns will be distributed differently.

Second, exchange rates risk affects foreign investments. In order to put both local and ADRS return distributions on the same footing, one might translate the local market prices into U.S. dollars. In this case, the distribution of the foreign exchange rate may influence the behavior of the resulting distribution. ADRs prices are affected by foreign exchange rates merely because ADRs may be converted to locally traded shares. When the exchange rate changes, ADR prices may change even if the locally traded share prices remain unchanged. Thus, any empirical work of possible arbitrage 
between ADRs and locally traded shares must come to grips with the exchange rate risk during the sample period. Park and Tavakkol(1994) find that returns of Japanese ADRs are not significantly different from the returns on the underlying shares traded in Japan. They also report that the return volatility of ADRs is larger than the underlying shares volatility. They find, however, that this larger volatility is the result of currency return's volatility and the covariance between the stock and the currency returns.

Third, differences in trading hours cause a lead-lag relationship in information transmission between the ADR and the local markets. Kim, Szakmary and Mathur (2000) show that uncertainty induced by non-synchronous trading hours of the ADRs and the underlying security, impede arbitrage activity.

Finally, Market liquidity is an important factor in analyses of return distributions, especially in emerging markets. It is important to realize that low local market liquidity may play important role in the statistical results. For example, Park and Tavakkol(1994) report that ADRs are traded in a much more liquid market than their corresponding shares. Many local markets trade under restrictions on foreign capital flows in and out of the market, restrictions which by themselves may create low trading liquidity and may bias some of the analysis. With less capital restrictions, however, the local market may become more efficient and we expect that higher level of liquidity will prevail if all else remains unchanged. Yet, when such restrictions are being lifted and the same time the market suffers from low level of liquidity the results may not be clear. We return to this point later.

In this paper we empirically compare the distributions of ADR returns and the returns on the locally traded shares in Chile and Argentina. We also compare the costs associates with arbitrage activities in these two countries. These comparisons are interesting because both countries are emerging economies with a similar free market orientation, both markets are in the same geographic region and thus, are expected to 
be impacted similarly by international economic trends. Moreover, the trading hours of locally traded shares in Argentina and Chile are virtually identical to the their ADRs trading hours on the NYSE, thereby minimizing and possibly eliminating any lead-lag effect of information dissemination in the various markets.

In our sample period, Argentina and Chile differed, however, in two important aspects. First, Chile maintained its own currency, the Chilean peso (CLP) while the Argentinean government implemented a successful currency board since 1990, fixing the Argentinean Peso (ARS) to the U.S. dollar until the end of 2001. Second, during the 1990s, Chile imposed several capital restrictions on foreign investments which were completely lifted only during 2000. Argentina, however, removed all impediments to foreign investments and cash flow movements as early as 1990. Therefore, a comparative analysis of their respective ADRs' returns and the returns on the locally traded shares may shed some light on the relationship between ADR returns and capital flow restrictions, foreign exchange rates, transaction costs and market liquidity in emerging markets.

In our sample (see Table 1,) we find that the return distributions of Chilean ADRs are significantly different from the distributions of the returns on their respective underlying Chilean shares. While the mean returns are the same, before as well as after their translation into US dollars, the return standard deviations are significantly larger for the ADR returns than for the returns on locally traded stocks in Chile. In contrast, Argentinean ADRs and their respective underlying shares have the same distribution of returns. Second. the estimated transaction costs associated with arbitrage activities are between $1 \%$ and $2 \%$ for Chilean ADRs, and smaller - between $0.66 \%$ and $1.65 \%$ - for the Argentinean ADRs. Moreover, the speed with which local prices adjust to arbitrage activities is significantly higher in Argentina: the estimated daily return spread reversion 
caused by arbitrage activities is around $40 \%$ for Argentinean ADRs while only $30 \%$ for Chilean ADRs, indicating that the Argentinean market is more efficient.

In order to analyze the impact of the capital restrictions removal in Chile during the end of the last decade, we partitioned the sample period into two parts; before and after 1998. The results are mixed possibly because in the time period during which Chile removed all capital restrictions on foreign investors, 1998 - 2001, its stock market experienced a much lower level of trading liquidity than earlier. Thus, while we find that lifting the capital restrictions and transaction costs were negatively related, the relation was not significant in our sample. We also rejected the hypothesis that there is no difference between the transaction costs in the two markets. Moreover, in a cross section regression of transaction costs on liquidity, measured by volume, we found that the main factor for differences between the two countries was liquidity.

This paper is organized as follows. Section II introduces the data and presents some preliminary statistical results. Section III compares the return distributions based on the behavior of the returns in the distributions' tails, mean returns and return volatility. Section IV estimates the transaction costs of arbitrage activities in both countries. Section $\mathrm{V}$ describes some of the impediments to capital movement in and out of Chile during the last decade and Section VI analyses the relationship between transaction costs and liquidity in both markets. Section VI concludes the paper.

\section{The Data}

The data analyzed in this paper are the daily returns on six locally traded Argentinian firms and fourteen locally traded Chilean firms and their respective NYSE traded ADRs. Local markets data was directly obtained from the Bolsa de Comercio de Santiago and from La Bolsa de Comercio de Buenos Aires. In general, the sample period was 1993 through 2001. The sample period is different for the different firms, 
however, depending on the dates that their ADRs started trading on the NYSE. However, at least 3 years of both local and ADR daily return information must be available for a stock to be included in the sample.

Both markets have been thin for some time during the sample period and there were non-trading days, especially in Chile. We could not obtain floor traders' bid and ask quotes thus, for the non-trading days we use zero returns in our data. We base this approach on Marshall and Walker (1999) who showed that the use of non-trading days in the analysis of the Chilean equity market does not cause any significant bias in the analysis of the return distribution.

Table 1 presents the firms, their daily volume in U.S. dollars and the respective sample periods. Table 2 exhibits several statistics of the data for the locally traded shares, $L$ and for the corresponding ADRs, A. The high kurtosis values across all the firms indicate that the return distributions are non-normal. The extreme values are reported in the last two columns of the table. We find that the left tail extreme return values, $\alpha$., tend to be larger in the ADR market. This occurs for four out of the six Argentinean firms and for eleven out of the fourteen Chilean firms. Furthermore, the right tail extreme return values, $\alpha_{+}$, tend to be larger than the left tail extreme return values in both the local and the ADR markets. If the distributions of the returns on the locally traded firms and their corresponding ADRs differ in the tails it may indicate that these firms are at different risk classes. Therefore, in the next section we test this hypothesis in order to verify that the firms in our sample are all in the same risk class.

\section{A Comparison of the Return Distributions}

In this section we use several parametric and non-parametric statistical tests in order to compare the return distributions of the locally traded stocks and their ADRs 
across the two countries. Following the last remarks in Section II, however, we begin the analysis with estimations and tests of the distributions tails. These are important tests because for direct comparisons it is necessary to have all the firms in the two markets belong to the same class risk. If the results indicate that the firms in our sample are in different risk classes then any comparison between the return distributions will be conditional on the firms being in different risk classes.

\section{Illa. The Return Distributions Tails}

The results in Table 2 clearly show that a high excess kurtosis of the returns distribution prevails in our data and it forces the rejection of normality of the distribution for all the firms in both countries under the traditional Jarque-Bera normality test. This departure from normality was also documented by Harvey (1995a, 1995b), Claessens, Dasgupta and Glen (1995), and Bekaert et al. (1998). Susmel (2000) argues that the main difference between stock returns in emerging markets and well-established markets lies in the behavior of the returns on the tails of the distribution, especially on the left tail. In order to ascertain that the firms in the local and the ADRs markets are in the same risk class we test the behavior of returns on their distributions' tails using extreme value theory. We use the Hill (1965) estimator; see the appendix for a brief discussion of this estimator. Table 2 presents the Hill (1965) right tail estimate, $\alpha_{+}$, and the left tail estimate, $\alpha$,, respectively. First, notice that the estimates for the firms in both countries are mainly between 2 and 3 and are quite similar, that is, tail probabilities in both countries are not different. Second, the tails for both the local shares and their corresponding ADRs are symmetric. That is, the magnitudes of the left tail estimates are not significantly different from the magnitudes of the right tail estimates. Third, the local shares do not have significantly different tails than their corresponding ADRs. 
In conclusion, the results point out that the behavior of extreme returns is similar in Chile and Argentina and that, for both countries, the distributions of the local shares and their corresponding ADRs are not different in the tails. This result indicates that the firms of the two countries are in the same risk class. They are fundamentally similar in this respect - the tails. We emphasize this result because it implies that any source of differences in the return distribution parameters may lie in factors such as exchange rate risk, transaction costs and market liquidity.

\section{IIllb. The Means and Standard Deviations of the Return Distributions}

We begin this section with three non-parametric tests of the returns' distributions equality across the markets. The results are shown in Table 3. The Kolmogorov-Smirnov (KS) test rejects the Null - equality of distributions - for only one firm from Argentina, namely, TGS but it rejects the equality of the return distributions across markets for all 14 Chilean firms. Note that the Wilcoxon, WS and the Median, MS, location tests fail to reject the null hypothesis for most Chilean firms, indicating that the differences found across markets for Chilean firms are related to some measure of dispersion, but not to the location of the return distributions. In order to better characterize the differences between the return distributions we next employ the Bradley and Blackwood (1989) parametric joint test of simultaneous means and variances equality.

Let $r_{j t}$ denote the return on a stock traded in country j, j = AR - Argentina, $\mathrm{CH}$ Chile at time $t$; rust denotes the return on the corresponding $A D R ; t=1,2, \ldots . T$. Assume that the return distributions are elliptical and define $Y_{t}=r_{j, t}-r_{U S, t} ; \quad X_{t}=r_{j t}+r_{U S, t}$ and $\mathrm{DEVX} \mathrm{X}_{t}=\mathrm{X}_{\mathrm{t}}-\overline{\mathrm{X}}$. Then, perform the following regression:

$$
Y_{t}=\beta_{0}+\beta_{1} D_{E V X}+e_{t} \quad t=1,2, \ldots, T
$$


Regression (1) yields an F value that tests the Null hypothesis: $\beta_{0}=0$ and $\beta_{1}=0$, against the alternative hypothesis that at least one of the coefficients is different from zero. That is, we test if the mean returns and the returns variances are simultaneously equal. If this Null cannot be rejected then the two distributions are the same. If the Null is rejected we follow Owen and Rabinovitch (1999), using the regression's t-values to test the equality of the means $\left(\beta_{0}=0\right)$ and the equality of the variances $\left(\beta_{1}=0\right)$, separately. Table 4 exhibits the results of these regressions. The simultaneous equality of the mean returns and the returns variances cannot be rejected for all but one case, for the Argentinean firms. Thus, the return distribution of the Argentinean ADRs is equal to the return distribution of the locally traded shares. For the Chilean firms, the F test rejects the simultaneous equality hypothesis for all the firms. Then, the t-tests show that while the mean returns are equal, the volatility of $A D R$ returns is significantly larger than the volatility of the returns on the locally traded shares for 9 out of the 14 Chilean firms.

The ADRs returns higher volatility may be attributed to several factors such as the effect of the exchange rate distribution on the return distribution and possibly, higher market liquidity in New York than in the local market in Santiago. As for the exchange rate distribution, we re ran all our tests with dollar denominated returns in Chile. The results were virtually the same. Thus, we hypothesize that the low level of market liquidity in Santiago, Chile relative to the NYSE liquidity may contribute to the volatility difference. We did not test this hypothesis.

There is another factor, however, that probably contribute to the difference between the return distributions across the two countries, namely, the cost of transacting in the two markets. We test this hypothesis in the next section.

\section{The cost of trading in Chile and Argentina.}


In this section we analyze possible effects of the different investment environments in Argentina and Chile on the returns distribution. Specifically, we test the hypothesis that trading transaction costs are significantly different across the two markets. These costs include the cost of trading locally on the exchanges in Buenos Aires and Santiago, as well as the cost of arbitrage activities. Arbitrage activities occur only if the price spread across these segmented markets exceeds the entire cost associated with arbitrage. Thus, we begin the analysis assuming that the prices in the ADR market and the local markets are the same and no arbitrage exists.

Suppose that at time the prices of an ADR and the locally traded shares are the same: $P_{t}(A)=P_{t}(L)$, so that arbitrage is not a possibility. Later, at time $t+1$, the prices in both markets may change but remain equal, keeping the no arbitrage state, or, they may differ, thereby creating arbitrage opportunity. This means that $P_{t+1}(A)$ may be equal, greater or, smaller than $\mathrm{P}_{\mathrm{t}+1}(\mathrm{~L})$ :

$$
\begin{aligned}
& P_{t}(A)=P_{t}(L) \\
& P_{t+1}(A)\left\{_{<}^{>}\right\} P_{t+1}(L) .
\end{aligned}
$$

Again, if the $P_{t+1}(A)>P_{t+1}(L)$ arbitrageurs will buy the ADRs and sell the locally traded shares. If $\mathrm{P}_{\mathrm{t}+1}(\mathrm{~A})<\mathrm{P}_{\mathrm{t}+1}(\mathrm{~L})$ arbitrageurs will buy the locally traded shares and sell the ADRs. These activities will cause the prices to adjust and new no arbitrage state will be reached. Notice that the above inequalities can be equivalently re written in return terms:

$$
\frac{\mathrm{P}_{\mathrm{t}+1}(\mathrm{~A})-\mathrm{P}_{\mathrm{t}}(\mathrm{A})}{\mathrm{P}_{\mathrm{t}}(\mathrm{A})} \underset{\{\underset{<}{=}\}}{>} \frac{\mathrm{P}_{\mathrm{t}+1}(\mathrm{~L})-\mathrm{P}_{\mathrm{t}}(\mathrm{L})}{\mathrm{P}_{\mathrm{t}}(\mathrm{L})},
$$

which is equivalent to:

$$
R_{t+1}(A)-R_{t+1}(L)\{\stackrel{>}{\stackrel{<}{<}}\} k
$$


In (2), the parameter $\mathrm{k}$ measures the transaction costs faced by arbitrageurs. The transaction costs include bid-ask spreads, commissions, opportunity costs, time delays, etc. From the above discussion it is clear that we can analyze the arbitrage activities with return spreads because they are equivalent to price spreads. This result follows because the ADR market and the local market prices must be equal if no arbitrage exists. Arbitrage occurs only if the price in one market is sufficiently higher than the price in the other market. Following arbitrage activities, the prices adjust and become equal again until the next time that they differ enough to bring arbitrage about. In the above analysis, if the return in the local market is greater (less) than the return in the ADR market, then the investor will buy ADRs and sell in the local market and vice versa. These activities are exactly the same activities that will occur if the price in the local market is greater than the price in the ADR market and vice versa. In the analysis which follows we use return spreads for yet, another reason. Returns, by their definition, lend themselves to analyzing the cost as percentage of return, which makes comparison of numbers across markets compatible. Thus, while arbitrage is based on the price spread being greater or smaller than some cost threshold, we can equivalently use the returns spreads. In addition, working with returns avoids all the unit root problems associated with working with price levels.

Let $y_{t}=R_{t}(L)-R_{t}(A)$ denote the return spread across the local and the ADR markets. The estimation of the cost parameter $\mathrm{k}$ is in two stages. In the first stage we test whether the return spreads follow a standard AR model or not. Under a standard AR linear model, there is no difference between the speed of adjustment of $y_{t}$ to small and large differences of returns in both markets. The last column of Table 5 reports the Lukkonnen, R., P. Saikkonen, and T. Terarsvirta, (1988) F-tests. The large F-values strongly reject the linearity hypothesis in all cases. Thus, we need to use a non linear model in order to estimate the cost parameter, k. We use Tong's (1983) non linear 
Threshold Autoregressive (TAR) model as an approximation for the arbitrage adjustment mechanism between the local and ADRs markets as follows:

$$
\begin{array}{ll}
y_{t}=\alpha_{\text {out }}+\beta_{\text {out }} y_{t-1}+e_{\text {out }, t} & \text { if }\left|y_{t-1}\right| \geq \kappa \\
y_{t}=\alpha_{\text {in }}+\beta_{\text {in }} y_{t-1}+e_{\text {in,t }} & \text { if }\left|y_{t-1}\right|<\kappa .
\end{array}
$$

In (3.1), $\beta_{\text {out }}$ measures the speed of convergence toward equilibrium, following arbitrage activity. Under the usual assumption, $e_{\text {out, }}$ follows a Nbrmal distribution, $N\left(0, \sigma_{\text {out }}^{2}\right)$ and $e_{\text {in,t }}$ follows a Normal distribution, $\mathrm{N}\left(0, \sigma^{2}{ }_{\text {in }}\right)$. Further, since daily returns are on average very small, we assume $\alpha_{\text {out }}=\alpha_{\text {in }}=0$.

Equation (3.1) describes the behavior of the returns spread when there are arbitrage opportunities, because the return spread is greater than the transaction costs, k. Following the arbitrage argument $\beta_{\text {out }}$ should be negative. Equation (3.2) describes the behavior of the returns spread when there are no arbitrage opportunities. That is, equilibrium without any arbitrage opportunities exists for all $y_{t}$ values in the interval [- $k$, $\mathrm{k}]$, and not just at the point 0 . Thus, inside the interval $[-\mathrm{k}, \mathrm{k}]$ there is no autoregressive behavior, which implies $\beta_{\text {in }}=0$.

A similar model, but applied to gold points, was used by Prakash and Taylor (1998). ${ }^{1}$ A recent paper by Eun and Sabherwal (2003) uses a similar approach to model return adjustments to deviation from equilibrium -i.e., no arbitrage- between shares trading in the U.S. and in Canada. They do not estimate transaction costs and thus they use a linear error correction representation for returns, where the error correction term measures the deviation from equilibrium.

1 This model is also in the spirit of the findings of Neumark, Tinsley and Tosini (1991), where they report evidence of nonzero transaction costs, state-dependent volatility and state-dependent "efficiency," for multiple listed securities. 
Note that model (3) above assumes that arbitrage activities bring the two markets back to the no-arbitrage equilibrium in one time period - one day, in our analysis. We return to this point later. There are four parameters to estimate $\beta_{\text {out }}, \sigma_{\text {out }}^{2}, \sigma_{\text {in }}^{2}$ and $k$. We follow Fanizza's (1990) estimation procedure of likelihood function maximization. ${ }^{2}$

Table 5 shows that the autoregressive parameter, $\beta_{\text {out }}$, is significant and negative in all the cases, as predicted by the arbitrage argument. For example, suppose that the ADRs of BRS have a $3 \%$ return while the local shares of BRS in Argentina have a $1 \%$ return. According to our estimate of $\beta_{\text {out, }}$ the following day, the local shares are expected to increase by almost $1 \%$ more than the ADRs trading in NYSE. We average the $\beta_{\text {out }}$ estimates over the firms in each market and see that the next day mean return spread reversion toward equilibrium is $44.8 \%$ for the Argentinean firms but only $34.1 \%$ for the Chilean firms.

The cost estimates, $\mathrm{k}$, indicate that he average transaction cost of trading in Argentina is 124.5 basis points with an estimated range of 83 to 178 basis points. By comparison, the average transaction cost faced by arbitrageurs in Chile is estimated at 172.5 basis points with a range of 81 to 312 basis points. Thus, on average, arbitrageurs in Argentina will require an additional $1.245 \%$ return before they will engage in arbitrage activities while arbitrage activities have to yield an additional $1.725 \%$ in Chile before arbitrage is profitable. The $28 \%$ of transaction costs spread of arbitrage between the two countries is significant at the $5 \%$ level, implying that it is costlier to carry out arbitrage activities in Chile.

The difference in the estimated transaction costs between Chile and Argentina may be the result of lower trading liquidity and the longer administrative process required

\footnotetext{
2 Following Fanizza (1990) and Balke and Fomby (1997), we use a best-fit grid search on the threshold parameter $\kappa$.
} 
in Chile in oder to exploit arbitrage opportunities. We leave the discussion of these hypotheses to the next section.

Here, however, we still focus on the estimation of the cost of arbitrage. Recall that model (3) assumes a one day adjustment process. One may argue that this model may underestimate the speed with which the returns adjust to arbitrage activities if it actually takes two days for the adjustment to take place. We, therefore, estimate an extended TAR model, by aggregating the returns of the previous two days into the threshold definition. Accordingly, model (3) becomes model (4) as follows:

$$
\begin{array}{ll}
\mathrm{y}_{\mathrm{t}}=\alpha_{\text {out }}+\beta_{\text {out }} \mathrm{y}_{\mathrm{t}-1}+\mathrm{e}_{\text {out }, \mathrm{t}} & \text { if }\left|\mathrm{y}_{\mathrm{t}-1}+\mathrm{y}_{\mathrm{t}-2}\right| \geq \mathrm{k} \\
\mathrm{y}_{\mathrm{t}}=\alpha_{\text {in }}+\beta_{\text {in }} \mathrm{y}_{\mathrm{t}-1}+\mathrm{e}_{\text {in,t }} & \text { if }\left|\mathrm{y}_{\mathrm{t}-1}+\mathrm{y}_{\mathrm{t}-2}\right|<\mathrm{k} .
\end{array}
$$

We find that the overall results are similar to the results presented in Table $5 .^{3}$ (Since the results are qualitative similar, we do not include the new Table.) As expected, the betas are higher than in Table 5. We found that for Argentina, the average $\beta_{\text {out }}$ increases (in absolute value) from -.419 to -.505. We also found that for Chile, the average $\beta_{\text {out }}$ increases (in absolute value) from -.308 to -.374. However, the $\beta_{\text {out }}$ 's are not significantly higher when the two-day return aggregation is included in the definition of the threshold. That is, the adjustment is statistically equivalent to the situation where the adjustment was assumed to happen in only day.

\section{The Effect of Capital Controls: A Two Sub Periods Approach.}

The results discussed in the previous section indicate that capital restriction in Chile may have contributed to the higher costs of transaction in Chile. Moreover, capital

3 We should point out that in terms of the likelihood function, the extended TAR model with two-day return aggregation, need not necessarily outperform the TAR model (3). In Argentina, the likelihood function is higher in only two out of six cases, while in Chile the likelihood function is higher in eight out of fourteen cases. Again, this result is consistent with the hypothesis that the Chilean market faces more binding restrictions than the 
controls may have been the cause of the slower price adjustment process in Chile by increasing the total cost of transactions. We address these issues in this section.

We reiterate that during the sample period Argentina allowed complete freedom to foreign investments and cash flow movements, while Chile imposed several restrictions on foreign investments. Although these restrictions were legally binding, it is not clear that they had any economic impact. It is quite possible that traders designed contracts and found loopholes, which enabled them to avoid some or all of these restrictions. Still, one may argue that the capital restrictions imposed in Chile may have affected arbitrage activities as follows: Suppose that the USD price of the locally traded stock is higher than the ADR price in New York. Then, an arbitrageur buys ADRs in the U.S. market in order to simultaneously sell them in the local market. These activities are instantaneous for the Argentinean firms. But, for the Chilean firms the arbitrageur must first, convert the ADRs into the underlying shares. The custodian bank reports the ADR conversion to the Chilean central bank and requires approval of: 1 . The exchange of the proceeds from the sale of the shares in the local market from Chilean peso into US dollars and 2. The transfer of the US dollars to the Uhited States. During most of the sample period the Chilean central bank had up to seven days to process the paper work and approve the foreign exchange transaction. Once the transaction was approved, the foreign investor was obliged to send dollars abroad in a period of no longer than five days. According to regulators, this maximum holding period was supposed to guarantee that foreign investors entered the local market for arbitrage activities and not to perform speculative operations. Table 6 presents a summary of the activities required to perform arbitrage along with the times and types of transaction costs involved. ${ }^{4}$ Table 7 summarizes the history of the major changes in the regulatory restrictions in Chile over

Argentine market.

${ }^{4}$ See http://www.duke.edu/ charvey/Country_risk/couindex.htm, for a more complete 
the last decade. From these tables it is clear that international arbitrage operations were subject to regulatory-induced time delays in both directions, delays that added to the cost of performing arbitrage activities across the markets.

Most of the capital controls were in effect during the first part of the sample period but, they have been virtually eliminated between 1998 and 2000. We, therefore, partitioned the sample period into two non overlapping sub periods: pre September 1998 and post this date. Two changes characterized the second period. First, as mentioned above, Chile has lifted most of the capital restrictions during this period. Thus, one would expect to find increased efficiency in Chile and hence, less differences between the two countries. The second change, however, may have worked in opposite direction. During the last three year of the sample period, both the Chilean and the Argentinean markets have experienced less trading liquidity than before 1998. Table 8 exhibits the results for the estimated model (3) for the two sub periods, i.e., before and after September 1998. The results in the table reflect the net effect of the two factors. On the one hand less capital restrictions and on the other hand less market liquidity.

Table 8 shows that the estimated speed of adjustment, $\beta_{\text {out }}$, decreased in Argentina from $51.35 \%$ on average before 1998 to $41.575 \%$ after 1998 . During the respective periods the estimated speed of adjustment decreased from $34.51 \%$ to $20.41 \%$ in Chile. The average transaction costs estimates increased in both countries, however. In Argentina they were 123.25 before 1988 and 134 basis points afterward while in Chile they were 164 basis points before 1988 and 193 basis points afterward. These results point out that liquidity seems to have a higher impact than capital restrictions (in absolute value) on transaction costs.

historical description of the market liberalization events in Chile. 


\section{Transaction Cost and Liquidity.}

The significant difference in transaction costs between the two countries may have existed not only because of the fact that in Argentina the exchange rate was pegged to the US dollar during the sample period and in Chile it was floating. It may reflect any difference in trading liquidity of the ADRs of the two countries. Observe, for example that Banco Rio with heavily traded ADRs entered the Argentinean market on 10/10/97, increasing the trading volume in Argentina during the second sub period. To test the null hypothesis that trading liquidity affected transaction costs, we run the following regression:

$$
\kappa_{i}=\alpha_{0}+\alpha_{1} D_{i}+\alpha_{2} Z_{i}+\varepsilon_{1}
$$

where $\kappa_{\mathrm{i}}$ represents the transaction costs estimated in Table $5, \mathrm{Z}$ represents a trading liquidity measure (ADR Volume, in thousands, or number of actual trading days -i.e., days with non zero volume- relative to total trading days), and $D_{i}$ is a dummy variable defined as:

$$
\begin{aligned}
D_{i} & =1 \text { if } \mathrm{i}=\text { Chile } \\
& =0 \text { if } \mathrm{i}=\text { Argentina }
\end{aligned}
$$

Thus, we ran a cross sectional regression of the transaction costs on liquidity and a country dummy variable. Liquidity is measured by average daily volume and also by the numbers of days with non-zero trading volume relative to total trading days. The coefficient of the liquidity variable is expected to be negative if higher volume means lower transaction cost. The dummy variable should pick up any differences between the two countries, like the different exchange rate regimes and different capital control policies. Table 9 shows that liquidity has a significant negative effect on transaction costs. The regression based on the percentage of actual trading days has a higher $\mathrm{R}^{2}$, pointing out that number of trading days is a better liquidity indicator than average 
volume for these markets. This result is consistent with Lesmond (2002), who presents evidence that the proportion of zero daily returns in emerging markets is related to common measures of both explicit and implicit transaction costs. The dummy variable is not significant, indicating that there was not a significant difference between the transaction cost and volume relationship in the two countries during the sample period. This result may indicate that the capital controls imposed in Chile were not effective. Arbitrageurs may have been able to avoid the restrictions so that the latter had little or no impact on arbitrage activities. Liquidity, on the other hand, did affect arbitrage activity.

\section{Conclusions}

In this paper we compare the distributions of ADR returns and the returns of the locally traded shares between Chile and Argentina. This comparison demonstrates several interesting points. First, we cannot reject the hypothesis that the returns distributions for the Argentinean ADRs and their underlying shares traded in Buenos Aires are equal. The Argentinean market is open on virtually the same hours as the market in New York, during the sample period Argentina had no impediments to foreign investment and cash flows movements and it maintained a continuous convertibility between its peso and the U.S. dollar. Moreover, the return spread adjustment was relatively quick as is indicated by the $42 \%$ average daily return spread reversion in Argentina. This means that there was little or no impediment to arbitrage activities in case arbitrage opportunities presented themselves. We point out, however, that an estimated average of $1.14 \%$ of return spread existed before arbitrage profit could be made. Chile, on the other hand, maintained a floating exchange rate between its peso and the US dollar. We find that this difference does not cause any change in the return distribution. Probably, the main reason for the higher return volatility of the ADRs is the higher liquidity of the ADRs market in New York. Other trading restrictions and 
regulations that impeded a free flow of cash into and from Chile did not seem to affect arbitrageurs. First, the results show that the daily return spread reversion in Chile is only $31 \%$, which means that the return spread adjustment took a longer time in Chile than in Argentina. Moreover, arbitrage activities that may lead to more efficiency were further impeded by the higher costs of transactions. The $1.37 \%$ of return that must be added before arbitrage profits could be made in Chile, was $20 \%$ higher than in Argentina. This significant difference may have driven international investors who were interested in the South American region towards investments in Argentina rather than in Chile. The analysis of the two sample sub periods indicates that it is possible that the main factor which affects the transaction costs of trading is market trading liquidity, not the different capital control policies.

In order to accommodate price adjustment delays for regulatory time constraints in Chile, we may need to introduce longer memory to the TAR(p;n,d) model, by varying the autoregressive parameter, $p$, and the delay parameter, $d$, or the number of thresholds, $\mathrm{n}$, which is equal to 1 in our model. Moreover, we may need to introduce returns accumulated over a period of several days. These extensions substantially complicate the TAR estimation and are possible extension of this work. 


\section{References}

Alexander, G., C. Eun and Janakiramanan, (1987), "Asset Pricing Dual Listing on Foreign Capital Markets: A Note," Journal of Finance, 42 151-158.

Bailey, W. and J. Jagtiani, (1994), "Foreign Ownership Restrictions and Stock Prices in the Thai Capital Market," Journal of Financial Economics, 36, 57-87.

Baker H. K., R. J. Mofsinger, and G. D. Weaver, (1999), "International Cross-Listing and Visibility," NYSE Working Paper 99-01.

Balke, N. S., and T. B. Fomby, (1997), "Threshold Cointegration," International Economic Review, 38, 627-646.

Bekaert, G., C. B. Erb, C. R. Harvey and T. E. Viskanta (1998), "Distributional Characteristics of Emerging Market Returns and Asset Allocation," Journal of Portfolio Management, Winter, 102-116.

Bekaert, G. and C. R. Harvey (1995), "Time-varying World Market Integration," Journal of Finance, 50, 2, 403-444.

Bekaert, G. and C. R. Harvey (1997), "Emerging Equity Market Volatility," Journal of Financial Economics, 43, 29-78.

Bradley, E.L. and L. G. Blackwood, (1989), "A Simultaneous test for Means and Variances," The American Statistician, 43, 234-235.

Claessens, S., S. Dasgupta and J. Glen, (1995), "Return Behavior in Emerging Stock Markets," World Bank Economic Review, 9, 131-151.

Domowitz, I., J. Glen and A., Madhavan, (1997a), "International Cross Listing and Order Flow Migration: Evidence from an Emerging Market," working paper.

Domowitz, I., J. Glen and A., MAdhavan (1997b), "Market segmentation and Stock Prices: Evidence from an Emerging Market," The Journal of Finance, 52, 1059 - 1085.

Edwards, S. and R. Susmel, (2000), "Time-Varying Correlations and Volatility Dependence en Emerging Equity Markets," Journal of Development Economics, forthcoming.

Errunza, V. and Losq Etienne, (1985), "International Asset Pricing Under Mild Segmentation: Theory and Test," The Journal Of Finance, 40, 105 - 124.

Errunza, V. and Losq Etienne, (1989), "Capital Flow Controls, International Asset Pricing and Investors' Welfare: A Multi-Country Framework," The Journal Of Finance, 44, 1025 -1038 .

Eun, C. and S. Janakiramanan, (1986), "A Model of International Asset Pricing With A Constraint On the Foreign Equity Ownership," The Journal Of Finance, 41, 897-913. 
Fanizza, D. G., (1990), "Multiple Steady States and Coordination Failures in Search Equilibrium: New Approaches to the Business Cycle," Ph.D. dissertation, Northwestern University.

Forester, and G. A. Karolyi, (1999), "The Effects of Market Segmentation and Investor Recognition on Asset Prices: Evidence from Foreign Stock Listing in the U.S.," Journal of Finance, 54, 981-1031.

Goldie, C. M. and R. L. Smith, (1987), "Slow Variation with Remainder: Theory and Applications," Quarterly Journal of Mathematics, 38, 45-71.

Harvey, C. R., (1995a), "Predictable Risk and Returns in Emerging Markets," Review of Financial Studies, 8, 773-816.

Harvey, C. R., (1995b), "The Risk Exposure of Emerging Equity Markets," World Bank Economic Review, 9, 19-50.

Hill, B. M., (1975), " A Simple General Approach to Inference About the Tail of a Distribution," The Annals of Statistics, 3, 1163-1173.

Howe, and I. Mathur, (1990), "The Impact of International Listing on Risk: Implications to Capital Market Integration," Journal of Banking and Finance, 14, 1133-1142.

Jayaraman, N., K. Shastry and K. Tandon, (1993), "The Impact of International Cross Listing on Risk and Return: Evidence from American Depositary Receipts," Journal of Banking and Finance, 17, 91-103.

Karolyi, G. A., (1998), "Why Do Companies List Shares Abroad? A Survey of the Evidence and Its Managerial Implications," Financial Markets, Institutions and Instruments, 7, 1-60.

Karolyi, G. A. and M. R. Stulz , (1996), "Why do Markets Move Together? An Investigation of U.S.-Japan Stock Return Comovements," Journal of Finance, 51, 957986.

Kato, K., S. Linn, and J. Schallheim, (1991), " Are There Arbitrage Opportunities in the Markets for American Depository Receipts?" Journal Of International Financial Markets, Institutions and Money,1, 13-32.

Kim, M., Szakmary, C. Andrew and Mathur, I., (2000), " Price Transmission Dynamics Between ADRs and their Underlying Foreign Securities," Journal of Banking \& Finance, $24,1359-1382$.

Koedijk, K. G, M. M. A. Schafgans and C. G. de Vries, (1990), "The Tail Index of Exchange Rate Returns," Journal of International Economics, 29, 93-108.

Leadbetter, M.R., G. Lindgren and H. Rootzen, (1983), Extreme and Related Properties of Random Sequences and Processes. Berlin, Germany: Springer-Verlag.

Lesmond, D. A., (2002), "The Costs of equity trading in emerging markets." Working paper. Tulane University. 
Lukkonnen, R., P. Saikkonen, and T. Terarsvirta, (1988), "Testing linearity against smooth transition autoregressive models," Biometrika, 75, 239-266.

Maldonado, R. and A. Saunders, (1983), "Foreign Exchange Restrictions and the Law of One Price," Financial Management, 12, 19-23.

Marshall, P. and E. Walker (1999), "Information Transmission and Serial Correlation Dependence of Short-run Returns," unpublished monograph. Escuela de Administracion, Universidad Catolica de Chile.

Merton, C. R., (1987), "Presidential address: A Simple Model of Capital Market Equilibrium With Incomplete Information," The Journal of Finance, 42, 483-123.

Miller, P. D., (1998), "The Market Reaction To International Cross-Listings: Evidence From Depository Receipts," Journal of Financial Economics, 51, 103-123.

Miller, P. D., and R. M. Morey, (1996), "The Intraday Pricing Behavior of International Dually Listed Securities," Journal of International Financial Markets, Institutions and Money, 6, 79-89.

Muscarell, J. C. and R. M. Vetsuypens, (1996), "Stock Splits: Signaling or Liquidity? The Case of ADR 'solo-splits'," Journal of Financial Economics, 42, 3-26.

Neumark, D., P. A. Tinsley, and S. Tosini (1991), "After-Hours Stock Prices and PostCrash Hangovers," Journal of Finance, 45, 159-178.

Newton, C. A. C. Jr., P. C. R. Leal, F. L. Celso, and P. L. P. Lambranho, ( ), "The Market Impact Of Cross-Listing: The Case of Brazilian ADRs," Emerging Markets Quarterly, Forthcoming.

Officer, D. and R. Hoffmeister, (1987), "ADRs: A Substitute for the Real Thing?," Journal of Portfolio Management, 13, 61-65.

Owen, J and Rabinovitch, R, (1999), "Ranking Portfolio Performance By a Joint Means and Variances Equality Test," Journal of Applied Economics, 2, 97-130.

Park, J. and A. Tavakkol, (1994), "Are ADRs A Dollar Translation of their Underlying Securities?: The Case of Japanese ADRs," Journal of International Financial Markets, Institutions \& Money, 4, $77-87$.

Patro, K D, (1999), "Return Behavior and Pricing of American Depository Receipts," working paper. Faculty of Management, Rutgers University.

Prakash, G. and M. A. Taylor, (1998), "Measuring Market Integration: A Model of Arbitrage With An Econometric Application To The Gold Standard, 1879-1913," working paper Series no. 6073, National Bureau of Economic Research.

Stulz, M. R., (1981), "On the Effects of Barriers to International Asset Pricing," Journal of Finance, 25, 783-794. 
Stulz M. R. and W. Wasserfallen, (1995), "Foreign Equity Investment Restrictions, Capital Flight and Shareholder Wealth Maximization: Theory and Evidence," The Review Of Financial Studies, 8, 1019 - 1058.

Susmel, R., (2002), "Extreme Observations and Diversification in Latin American Emerging Equity Markets," Journal of International Money and Finance, 971-986. December 2001.

Lukkonnen, R., P. Saikkonen, and T. Terarsvirta, (1988), "Testing linearity against smooth transition autoregressive models," Biometrika, 75, 239-266.

Tong, H., (1990), Threshold Models in Non-linear Time Series Analysis. Lecture Notes in Statistics, 21. Berlin: Springer.

Tsay, R. S., (1989), "Testing And Modeling Threshold Autoregressive Processes," Journal of the American Statistical Association, 84, 231-240.

Wahab, M. and A. Khandwala, (1993), "Why Diversify Internationally With ADRs?," Journal Of Portfolio Management, 20, 75-82.

Wahab, M., M. Lashgari, and R. Cohn, (1992), " Arbitrage in the American Depository Receipts Market Revisited," Journal Of International Markets, Institutions and Money, 2, 97-130

Walker, H. M. and Lev, J., (1953), Statistical Inference. Holt, Rinehart and Winston. 


\section{Appendix: Tail Estimation}

Consider the stationary sequence $\mathrm{X}, \mathrm{X}_{2}, \ldots, \mathrm{X}_{\mathrm{n}}$ of i.i.d random variables with a distribution function $\mathrm{F}($.$) . We denote the probability that the maximum of the first \mathrm{n}$ random variables, $M_{h}$, is below a certain value, $x$, by $P\left(M_{h}<x\right)=F^{n}(x)$. $M_{h}$ could be multiplied by -1 if one is interested in the minimum. The distribution function $F^{n}(x)$, when suitably normalized and for large $n$, converges to a limiting distribution $G(x)$, where $G(x)$ is one of three known asymptotic distributions, see Leadbetter, Lindgren and Rootzen (1983). Since returns on financial assets are fat tailed, Koedijk, Schafgans and De Vries (1990) consider the family of limiting distributions of $\mathrm{G}(\mathrm{x})$ which is characterized by a lack of some higher moments:

$$
\begin{array}{ll}
G(x)=\exp (-x)^{-1 / \alpha}=\exp (-x)^{-\gamma}, & \text { if } x>0, \\
G(x)=0, & \text { if } x \leq 0 .
\end{array}
$$

where $\alpha$ is the tail index and $\gamma=1 / \alpha>0$. The tail index, $\gamma$, indicates the number of moments that exist. Leadbetter, Lindgren and Rootzen (1983) show that when the dependence in the $X_{i}^{\prime} s$ is not too strong, this limiting distribution is valid. For example, the Student-t with $\alpha$ degrees of freedom, the stable distribution with $\alpha<2$ and the ARCH process are members of $G(x)$. Using the sample order statistics $X_{(n)}, X_{(n-1)}, \ldots, X_{(1)}$ where, $X_{(n)}>X_{(n-1)}>\ldots>X_{(1)}$, the Hill (1975) estimator of $\gamma$ is given by:

$$
?=\frac{1}{m} \sum_{i=1}^{\mathrm{i}=\mathrm{m}}\left[\ln \left(\mathrm{X}_{\mathrm{n}+1-\mathrm{i}}\right)-\ln \left(\mathrm{X}_{\mathrm{n}-\mathrm{m}}\right]\right.
$$

where $m$ is the number of upper order statistics included. Goldie and Smith (1987) show that the Hill estimator is asymptotically normal. 


\section{TABLE 1. DATA DESCRIPTION}

\begin{tabular}{|c|c|c|c|c|c|c|}
\hline Firm & $\begin{array}{l}\text { Ticker } \\
\text { symbol }\end{array}$ & Industry & $\begin{array}{l}\text { Sample: Start of } \\
\text { ADR trading-end }\end{array}$ & $\begin{array}{l}\text { Market } \\
\text { Cap. } \\
\text { (USD } \\
\text { million) }\end{array}$ & $\begin{array}{c}\text { ADR } \\
\text { Daily } \\
\text { Volume } \\
\text { (USD) }\end{array}$ & $\begin{array}{c}\text { Local } \\
\text { Daily } \\
\text { Volume } \\
\text { (USD) } \\
\end{array}$ \\
\hline \multicolumn{7}{|l|}{ ARGENTINA } \\
\hline Banco Frances & BFR & Banking & $11 / 24 / 93-5 / 24 / 00$ & 1,340 & $2,034,281$ & 467,910 \\
\hline Banco Rio de la Plata & BRS & Banking & $10 / 10 / 97-5 / 24 / 00$ & 2,380 & 53,300 & 46,494 \\
\hline YPF S.A. & YPF & Oil \& Gas Operator & $07 / 07 / 93-5 / 24 / 00$ & 12,200 & 760,912 & 69,240 \\
\hline Telefonica de Argentina & TAR & Telecommunication & $03 / 08 / 94-5 / 24 / 00$ & 7,680 & 752,675 & 78,220 \\
\hline Telecom Argentina STET & TEO & Telecommunication & $12 / 09 / 94-5 / 24 / 00$ & 2,180 & $2,500,506$ & $3,430,048$ \\
\hline Transportadora de Gas S.A. & TGS & Gas \& Oil Operation & $11 / 17 / 94-5 / 24 / 00$ & 1240 & 405,328 & 96,316 \\
\hline \multicolumn{7}{|l|}{ CHILE } \\
\hline Compañia Cervecerias & $\mathrm{CU}$ & Beverages & $09 / 28 / 93-04 / 13 / 99$ & 1,430 & $1,537,202$ & 290,883 \\
\hline Viña Concha y Toro & $\mathrm{VCO}$ & Alcoholic beverage & $10 / 17 / 94-04 / 13 / 99$ & 535.8 & 353,276 & 76,480 \\
\hline Cristalerias de Chile & CGW & Glass products & $04 / 13 / 90-04 / 13 / 99$ & 369.3 & 537,625 & 224,958 \\
\hline Compañia de Telecom. de Chile & CTC & Telecommunication & $07 / 23 / 90-04 / 13 / 99$ & 4,410 & $7,100,795$ & $1,775,235$ \\
\hline Banco de A. Edwards & AED & Banking & $11 / 06 / 95-04 / 13 / 99$ & 493.4 & 407,405 & 216,570 \\
\hline Empresa Nac. Elec. (ENDESA) & EOC & Energy & $07 / 28 / 94-04 / 13 / 99$ & 3,200 & $1,953,955$ & $3,103,186$ \\
\hline Enersis S.A. & ENI & Electric utility & $10 / 21 / 93-04 / 13 / 99$ & 2960 & $2,145,629$ & $2,857,560$ \\
\hline Laboratorio Chile S.A. & LBC & Biotech & $07 / 01 / 94-04 / 13 / 99$ & 307.1 & 517,699 & 236,467 \\
\hline Madeco S.A. & MAD & Misc. Fabric. Prods. & $06 / 01 / 93-04 / 13 / 99$ & 299.1 & 506,970 & 156,033 \\
\hline Masisa S.A. & MYS & Constr. Supplies & $06 / 18 / 93-04 / 13 / 99$ & 353.7 & 338,258 & 247,357 \\
\hline Administradora Fondos Provida & PVD & Insurance & $04 / 17 / 94-04 / 13 / 99$ & 5410 & 661,247 & 112,439 \\
\hline Banco Santander Chile & BSB & Banking & $11 / 15 / 94-04 / 13 / 99$ & 1,720 & 883,675 & 225,613 \\
\hline Soc. Quimica y Minera de Chile & SQM & Chemical Industry & $09 / 22 / 93-04 / 13 / 99$ & 278.4 & 872,459 & 659,501 \\
\hline Santa Isabel & ISA & Retail (grocery) & $08 / 01 / 95-04 / 13 / 99$ & 195.2 & 231,532 & 259,095 \\
\hline
\end{tabular}

Notes:

Market Cap: Market Capitalization calculated at end of period. 
TABLE 2. UNIVARIATE RESULTS

Summary statistics for daily returns on locally traded stocks (L) and their NYSE ADRs (A). The calculated statistics are the mean, the standard deviation (SD), skewness coefficient (Skew), excess kurtosis (Kurt), maximum, fifth largest observation (max5), fifth lowest observation $(\min 5)$, minimum observation $(\min 1)$, right tail $\left(\alpha_{+}\right)$, and left tail $\left(\alpha_{-}\right)$.

\begin{tabular}{|c|c|c|c|c|c|c|c|c|c|c|c|}
\hline \multicolumn{2}{|c|}{ Ticker } & mean & SD & Skew & Kurt & $\max 1$ & $\max 5$ & $\min 5$ & $\min 1$ & $\alpha_{+}$ & $\alpha$ \\
\hline \multicolumn{12}{|c|}{ ARGENTINA } \\
\hline \multirow[t]{2}{*}{ BFR } & $\mathrm{L}$ & .0151 & 3.142 & 0.445 & 6.962 & 27.764 & 11.821 & -11.551 & -16.246 & 3.739 (.44)\# & $2.303(.23)$ \\
\hline & $\mathrm{A}$ & -.0098 & 3.202 & 0.211 & 5.686 & 21.401 & 11.957 & -12.411 & -19.083 & $2.447(.25)$ & $2.614(.46)$ \\
\hline \multirow[t]{2}{*}{ BRS } & $\mathrm{L}$ & -.0425 & 3.265 & -0.494 & 5.976 & 15.749 & 9.531 & -12.629 & -17.451 & $2.298(.38)$ & $2.139(.44)$ \\
\hline & $\mathrm{A}$ & -.0384 & 3.477 & -0.205 & 7.707 & 22.314 & 11.249 & -11.912 & -21.622 & $2.250(.39)$ & $3.327(.76)$ \\
\hline \multirow{2}{*}{ YPF } & $\bar{L}$ & .0428 & 2.041 & 0.329 & 7.299 & 15.864 & 9.215 & -8.613 & -12.613 & $2.521(.30)$ & $2.497(.25) \#$ \\
\hline & $\mathrm{A}$ & .0337 & 2.110 & 0.219 & 6.337 & 15.141 & 9.531 & -9.171 & -12.143 & $2.058(.19)$ & $2.045(.19)$ \\
\hline \multirow[t]{2}{*}{ TAR } & $\mathrm{L}$ & .0268 & 2.900 & 0.718 & 7.666 & 23.333 & 13.976 & -10.629 & -16.161 & $2.878(.30) \#$ & 2.852 (.30)\# \\
\hline & $\mathrm{A}$ & .0255 & 2.948 & -0.386 & 15.94 & 25.489 & 15.534 & -9.704 & -30.619 & 2.699 (.24)\# & $2.813(.27) \#$ \\
\hline \multirow[t]{2}{*}{ TEO } & $\mathrm{L}$ & -.0075 & 2.871 & 0.305 & 5.347 & 19.957 & 13.249 & -10.500 & -16.352 & $3.302(.50) \#$ & $2.517 \#(.24)$ \\
\hline & A & .0089 & 2.876 & -0.012 & 4.889 & 18.999 & 12.527 & -8.701 & -17.638 & $2.605(.31)$ & $2.675(.25) \#$ \\
\hline \multirow[t]{2}{*}{ TGS } & $\mathrm{L}$ & .0214 & 2.267 & -0.298 & 8.575 & 13.946 & 9.109 & -8.516 & -16.115 & $2.424(.31)$ & $2.645(.61)$ \\
\hline & $\mathrm{A}$ & .0266 & 2.292 & -0.105 & 8.625 & 14.974 & 9.379 & -8.311 & -19.498 & $2.614(.29) \#$ & $2.608(.28) \#$ \\
\hline \multicolumn{12}{|l|}{ CHILE } \\
\hline \multirow[t]{2}{*}{$\mathrm{CU}$} & $\mathrm{L}$ & 0.048 & 2.139 & 0.909 & 10.261 & 14.835 & 9.589 & -7.500 & -12.289 & $2.215(.31)$ & $2.306(.37)$ \\
\hline & $\mathrm{A}$ & 0.049 & 2.259 & 1.006 & 8.108 & 14.286 & 12.069 & -8.065 & -11.856 & $2.767(.40)$ & $2.121(.20)$ \\
\hline \multirow[t]{2}{*}{$\mathrm{VCO}$} & $\mathrm{L}$ & 0.085 & 1.920 & 0.617 & 6.648 & 11.554 & 8.527 & -6.081 & -8.996 & $2.134(.29)$ & $2.172(.29)$ \\
\hline & $\overline{\mathrm{A}}$ & 0.068 & 2.143 & 0.2513 & 3.737 & 12.346 & 8.152 & -7.910 & -9.848 & $3.129(.52) \#$ & $3.113(51) \#$ \\
\hline \multirow[t]{2}{*}{$\mathrm{CGW}$} & $\mathrm{L}$ & -0.018 & 2.180 & 0.560 & 10.348 & 16.818 & 7.234 & -8.297 & -12.037 & $2.602(.34)$ & $2.638(.38) \#$ \\
\hline & $\mathrm{A}$ & -0.053 & 2.388 & 0.5426 & 8.794 & 20.588 & 8.451 & -8.511 & -11.236 & $2.713(.43)$ & $2.656(.44)$ \\
\hline \multirow[t]{2}{*}{ CTC } & $\mathrm{L}$ & 0.132 & 1.909 & 0.556 & 7.373 & 16.352 & 8.899 & -7.809 & -13.006 & $2.871(.29)$ & $2.845(.25) \#$ \\
\hline & $\overline{\mathrm{A}}$ & 0.106 & 2.064 & 0.376 & 8.584 & 17.731 & 9.804 & -8.295 & -13.548 & $2.359(.20)$ & $2.185(.21)$ \\
\hline \multirow[t]{2}{*}{ AED } & $\mathrm{L}$ & -0.013 & 2.387 & 0.564 & 10.66 & 17.647 & 10.000 & -9.343 & -13.830 & $2.026(.27)$ & $1.688(.18)$ \\
\hline & $\mathrm{A}$ & -0.013 & 2.598 & -0.324 & 11.22 & 14.130 & 10.370 & -10.256 & -20.896 & $2.148(.28)$ & $2.157(.45)$ \\
\hline \multirow[t]{2}{*}{ EOC } & $\mathrm{L}$ & -0.010 & 1.879 & 1.060 & 8.855 & 17.647 & 7.422 & -6.061 & -7.143 & 3.017 (.38)\# & $3.362(.46) \#$ \\
\hline & $\mathrm{A}$ & -0.023 & 2.151 & 0.654 & 4.154 & 15.663 & 8.036 & -7.059 & -8.824 & $3.333(.48) \#$ & $3.189(.60) \#$ \\
\hline \multirow[t]{2}{*}{ ENI } & $\mathrm{L}$ & 0.041 & 2.035 & 0.678 & 4.529 & 14.894 & 8.000 & -6.906 & -8.333 & 3.747 (.50)\# & $2.874(.29) \#$ \\
\hline & $\bar{A}$ & 0.030 & 2.302 & -.0593 & 6.235 & 13.740 & 8.671 & -8.125 & -18.443 & $2.735(.43)$ & $2.721(.39) \#$ \\
\hline \multirow[t]{2}{*}{ LBC } & $\mathrm{L}$ & 0.0691 & 2.334 & 0.410 & 4.319 & 13.462 & 9.091 & -7.813 & -12.152 & $2.621(.37)$ & $2.598(.34)$ \\
\hline & $\mathrm{A}$ & 0.0638 & 2.5138 & 0.509 & 7.87 & 18.333 & 10.377 & -9.783 & -15.190 & $2.267(.25)$ & $2.247(.27)$ \\
\hline \multirow[t]{2}{*}{ MAD } & $\mathrm{L}$ & 0.0003 & 2.6728 & -0.437 & 10.056 & 17.682 & 9.259 & -13.043 & -19.318 & $2.293(.28)$ & $3.696(1.39)$ \\
\hline & $\mathrm{A}$ & -0.018 & 2.834 & 0.436 & 17.768 & 29.655 & 10.007 & -11.286 & -22.321 & $1.928(.21)$ & $2.582(.54)$ \\
\hline \multirow[t]{2}{*}{ MYS } & $\mathrm{L}$ & -0.007 & 2.5524 & 0.759 & 6.897 & 18.750 & 10.811 & -9.722 & -11.765 & $2.652(.26)$ & 2.609 (.25)\# \\
\hline & $\mathrm{A}$ & -0.016 & 2.7226 & 0.647 & 8.718 & 22.581 & 11.404 & -9.780 & -18.182 & $2.343(.21)$ & $2.369(.23) \#$ \\
\hline \multirow[t]{2}{*}{ PVD } & $\mathrm{L}$ & 0.0433 & 2.121 & 0.219 & 12.631 & 15.517 & 6.765 & -7.500 & -14.706 & $1.961(.29)$ & $2.140(.29)$ \\
\hline & $\bar{A}$ & 0.0222 & 2.0927 & 0.236 & 2.933 & 10.494 & 7.273 & -6.406 & -9.821 & $2.085(.20)$ & $2.079(.21)$ \\
\hline \multirow[t]{2}{*}{ BSB } & $\mathrm{L}$ & 0.0572 & 2.4335 & 0.014 & 12.963 & 18.182 & 9.677 & -9.091 & -19.149 & $2.116(.31)$ & $2.143(.62)$ \\
\hline & $\overline{\mathrm{A}}$ & 0.0538 & 2.749 & -0.115 & 11.152 & 17.647 & 11.111 & -11.215 & -22.283 & $2.156(.29)$ & $2.284(.35)$ \\
\hline \multirow[t]{2}{*}{ SQM } & $\mathrm{L}$ & -0.001 & 2.0333 & -0.571 & 7.666 & 10.536 & 7.131 & -9.343 & -17.237 & $2.335(.23)$ & $2.774(.37) \#$ \\
\hline & $\mathrm{A}$ & -0.001 & 2.0267 & -0.520 & 7.496 & 11.350 & 7.379 & -9.685 & -17.907 & $2.103(.20)$ & $2.434(.28)$ \\
\hline ISA & $\mathrm{L}$ & 0.0270 & 2.3782 & -0.274 & 8.778 & 12.245 & 8.597 & -7.563 & -15.349 & $2.139(.22)$ & $2.065(.22)$ \\
\hline & $\bar{A}$ & -0.001 & 2.8815 & -0.914 & 19.046 & 16.260 & 12.503 & -10.373 & -28.358 & $1.879(.24)$ & $1.878(.24)$ \\
\hline
\end{tabular}

Notes: \#: significantly different from 2.

$\alpha_{+}$: right tail estimate

$\alpha .:$ left tail estimate 
TABLE 3. NON PARAMETRIC TWO-SAMPLE TESTS

Comparisons of daily return distributions for locally traded stocks and their NYSE ADRs. The value for the Kolmogorov-Smirnov statistic, KS, was calculated, its asymptotic statistic, KSa, is reported (p-value in parenthesis). The value of the Wilcoxon Ranks Sums test, WS, is calculate, its $\mathrm{Z}$ score, WZ, is reported (p-value in parenthesis). The value of the Median Scores test, MS, is calculated, its $\mathrm{Z}$ score $\mathrm{MZ}$ is reported ( $\mathrm{p}$-value in parenthesis).

\begin{tabular}{|c|c|c|c|}
\hline \multirow[t]{2}{*}{ Ticker } & Kolmogorov-Smirnov test & Wilcoxon Rank Sums test & $\begin{array}{l}\text { Median Scores (Number of Points } \\
\text { Above Median) test }\end{array}$ \\
\hline & $\mathrm{KSa}$ & WZ & MZ \\
\hline \multicolumn{4}{|c|}{ ARGENTINA } \\
\hline BFR & $\begin{array}{c}0.707 \\
(0.699)\end{array}$ & $\begin{array}{c}-.02328 \\
(0.981)\end{array}$ & $\begin{array}{l}-0.6767 \\
(0.497)\end{array}$ \\
\hline BRS & $\begin{array}{c}.5954 \\
(0.870)\end{array}$ & $\begin{array}{l}0.3256 \\
(0.745)\end{array}$ & $\begin{array}{c}0.2280 \\
(0.8196)\end{array}$ \\
\hline YPF & $\begin{array}{l}0.9563 \\
(0.320)\end{array}$ & $\begin{array}{c}0.3997 \\
(0.6894)\end{array}$ & $\begin{array}{c}0.5426 \\
(0.5874)\end{array}$ \\
\hline TAR & $\begin{array}{l}0.0326 \\
(0.416) \\
\end{array}$ & $\begin{array}{l}0.3331 \\
(0.739) \\
\end{array}$ & $\begin{array}{l}0.5261 \\
(0.599) \\
\end{array}$ \\
\hline TEO & $\begin{array}{l}0.02532 \\
(0.783)\end{array}$ & $\begin{array}{l}0.2372 \\
(0.813)\end{array}$ & $\begin{array}{l}0.3008 \\
(0.764)\end{array}$ \\
\hline TGS & $\begin{array}{c}1.5812 \\
(0.014)^{*} \\
\end{array}$ & $\begin{array}{l}-0.02935 \\
(0.977) \\
\end{array}$ & $\begin{array}{r}-0.5034 \\
(0.615) \\
\end{array}$ \\
\hline \multicolumn{4}{|l|}{ CHILE } \\
\hline $\mathrm{CU}$ & $\begin{array}{l}2.3403^{*} \\
(0.0001) \\
\end{array}$ & $\begin{array}{c}0.7270 \\
(0.4672) \\
\end{array}$ & $\begin{array}{c}0.7575 \\
(0.4487) \\
\end{array}$ \\
\hline $\mathrm{VCO}$ & $\begin{array}{l}2.2661 * \\
(0.0001)\end{array}$ & $\begin{array}{c}0.3246 \\
(0.7455) \\
\end{array}$ & $\begin{array}{c}1.6154 \\
(0.1062) \\
\end{array}$ \\
\hline CGW & $\begin{array}{l}3.8184^{*} \\
(0.0001) \\
\end{array}$ & $\begin{array}{r}1.8665 \\
(0.0620) \\
\end{array}$ & $\begin{array}{c}-.4371 \\
(0.6620) \\
\end{array}$ \\
\hline CTC & $\begin{array}{l}1.7799^{*} \\
(0.0035)\end{array}$ & $\begin{array}{c}-.6919 \\
(0.4890)\end{array}$ & $\begin{array}{l}0.3025 \\
(0.7623)\end{array}$ \\
\hline AED & $\begin{array}{l}2.6833^{*} \\
(0.0001)\end{array}$ & $\begin{array}{c}0.7720 \\
(0.4401)\end{array}$ & $\begin{array}{l}-1.7923 \\
(0.0731)\end{array}$ \\
\hline $\mathrm{EOC}$ & $\begin{array}{l}2.2212 * \\
(0.0001) \\
\end{array}$ & $\begin{array}{c}0.5215 \\
(0.6020) \\
\end{array}$ & $\begin{array}{r}-2.0016^{*} \\
(0.0453) \\
\end{array}$ \\
\hline ENI & $\begin{array}{l}1.3702 * \\
(0.0468)\end{array}$ & $\begin{array}{c}0.0730 \\
(0.9418)\end{array}$ & $\begin{array}{r}-2.3383^{*} \\
(0.0194) \\
\end{array}$ \\
\hline LBC & $\begin{array}{l}3.0537 * \\
(0.0001)\end{array}$ & $\begin{array}{c}0.6583 \\
(0.5103)\end{array}$ & $\begin{array}{c}1.4575 \\
(0.1450)\end{array}$ \\
\hline MAD & $\begin{array}{l}3.3619 * \\
(0.0001)\end{array}$ & $\begin{array}{c}1.8493 \\
(0.0644)\end{array}$ & $\begin{array}{c}-.0495 \\
(0.9605)\end{array}$ \\
\hline MYS & $\begin{array}{l}2.9912 * \\
(0.0001)\end{array}$ & $\begin{array}{c}0.8049 \\
(0.4209)\end{array}$ & $\begin{array}{c}-2.0635^{*} \\
(0.0391)\end{array}$ \\
\hline PVD & $\begin{array}{l}2.7361 * \\
(0.0001) \\
\end{array}$ & $\begin{array}{c}1.5879 \\
(0.1123) \\
\end{array}$ & $\begin{array}{c}1.6611 \\
(0.0967) \\
\end{array}$ \\
\hline BSB & $\begin{array}{l}2.9420 * \\
(0.0001) \\
\end{array}$ & $\begin{array}{c}0.8289 \\
(0.4071) \\
\end{array}$ & $\begin{array}{c}1.0492 \\
(0.2941) \\
\end{array}$ \\
\hline SQM & $\begin{array}{l}1.4030 * \\
(0.0390)\end{array}$ & $\begin{array}{c}0.2736 \\
(0.7844) \\
\end{array}$ & $\begin{array}{c}0.0406 \\
(0.9676) \\
\end{array}$ \\
\hline ISA & $\begin{array}{l}3.1600^{*} \\
(0.0001) \\
\end{array}$ & $\begin{array}{c}1.0838 \\
(0.2784) \\
\end{array}$ & $\begin{array}{c}1.3083 \\
(0.1908) \\
\end{array}$ \\
\hline
\end{tabular}

Notes:

- * significant at the $5 \%$ level. 
TABLE 4. MEAN-VARIANCE RESULTS

This table presents parameter estimates and test statistics (in parenthesis) for the equality tests based on Owen and Rabinovitch (1999) using the following regression:

$\mathrm{y}_{\mathrm{t}}=\beta_{0}+\beta_{1} \mathrm{DEVX}_{\mathrm{t}}+\mathrm{e}_{\mathrm{t}}$

$\mathrm{y}_{\mathrm{t}}=\mathrm{r}_{\mathrm{J}, \mathrm{t}}-\mathrm{r}_{\mathrm{US}, \mathrm{t}}$

$\mathrm{x}_{\mathrm{t}}=\mathrm{r}_{\mathrm{J}, \mathrm{t}} \mathrm{r}_{\mathrm{US}, \mathrm{t}}$

$\operatorname{DEVX}_{\mathrm{t}}=\mathrm{x}_{\mathrm{t}} \bar{x}$

$\mathrm{J}=$ Argentina, Chile

The F-test tests joint means and variances equality test $\left(\mathrm{H}_{0}: \beta_{0}=0\right.$ and $\left.\beta_{1}=0\right)$ The t-statitiscs can be used to test $\beta_{0}=0$ and $\beta_{1}=0$ separately.

\begin{tabular}{|c|c|c|c|}
\hline \multirow[t]{2}{*}{ Ticker } & \multicolumn{3}{|c|}{ Equality test } \\
\hline & constant $\left(\beta_{0}\right)$ & $\operatorname{DEVX}_{\mathrm{t}}\left(\beta_{1}\right)$ & F-test \\
\hline \multicolumn{4}{|c|}{ ARGENTINA } \\
\hline BFR & $-0.025(0.51)$ & $-0.0103(-1.29)$ & 0.958 \\
\hline BRS & $-0.007(0.11)$ & $-0.033(3.36)^{*}$ & $5.625^{*}$ \\
\hline YPF & $-0.013(0.15)$ & $-0.329(1.40)$ & 0.984 \\
\hline TAR & $0.001(0.02)$ & $-0.010(0.79)$ & 0.309 \\
\hline TEO & $0.016(.46)$ & $-0.001(.15)$ & 0.344 \\
\hline TGS & $-0.005(0.09)$ & $-0.006(-0.50)$ & 0.128 \\
\hline \multicolumn{4}{|l|}{ CHILE } \\
\hline $\mathrm{CU}$ & $0.00027(0.61)$ & $-0.35342(-3.27) *$ & $5.348 *$ \\
\hline $\mathrm{VCO}$ & $-0.00005(-0.08)$ & $-0.04399(-2.25) *$ & $2.538 *$ \\
\hline CGW & $0.00034(0.50)$ & $-0.00395(-0.22)$ & 0.025 \\
\hline CTC & $0.00010(0.33)$ & $-0.03696(-4.66) *$ & $10.839 *$ \\
\hline AED & $-0.00051(-0.64)$ & $0.02299(1.15)$ & 0.667 \\
\hline $\mathrm{EOC}$ & $0.000009(0.02)$ & $-0.05461(-5.33) *$ & $14.226 *$ \\
\hline ENI & $0.00021(0.53)$ & $-0.04823(-5.24) *$ & $13.729 *$ \\
\hline LBC & $0.00019(0.32)$ & $-0.03015(-2.31) *$ & $2.678 *$ \\
\hline MAD & $0.00005(0.07)$ & $0.00421(0.28)$ & 0.039 \\
\hline MYS & $-0.00016(-0.27)$ & $-0.02305(-1.86)$ & 1.736 \\
\hline PVD & $0.00097(1.36)$ & $-0.00919(-0.44)$ & 0.096 \\
\hline BSB & $0.00051(0.71)$ & $-0.04745(-2.48) *$ & $3.079 *$ \\
\hline SQM & $-0.00012(-0.31)$ & $0.02546(2.65) *$ & $3.524 *$ \\
\hline ISA & $-0.00058(-0.71)$ & $-0.06303(-3.14) *$ & $4.943 *$ \\
\hline
\end{tabular}

Notes:

* significant at the $5 \%$ level. 
TABLE 5. ESTIMATION OF TRANSACTION COSTS

This table estimates the transaction costs of opening opposite positions in the locally traded shares and their ADRs, based on the (3.1) and (3.2) model:

$$
\begin{aligned}
& \mathrm{y}_{\mathrm{t}}=\alpha_{\text {out }}+\beta_{\text {out }} \mathrm{y}_{\mathrm{t}-1}+\mathrm{e}_{\text {out },}, \quad \text { if }\left|\mathrm{y}_{\mathrm{t}-1}\right|>\kappa \\
& \mathrm{y}_{\mathrm{t}}=\alpha_{\text {in }}+\beta_{\text {in }} \mathrm{y}_{\mathrm{t}-1}+\mathrm{e}_{\text {in, },}, \quad \text { if }\left|\mathrm{y}_{\mathrm{t}-1}\right|=\kappa \\
& \mathrm{y}_{\mathrm{t}}=\mathrm{r}_{\mathrm{J}, \mathrm{t}}-\mathrm{r}_{\mathrm{US}, \mathrm{t}} \\
& \mathrm{e}_{\text {out }, \mathrm{t}} \sim \mathrm{N}\left(0, \sigma_{\text {out }}\right), \mathrm{e}_{\mathrm{in}, \mathrm{t}} \sim \mathrm{N}\left(0, \sigma^{2}{ }_{\text {in }}\right) . \\
& \mathrm{J}=\text { Argentina, Chile }
\end{aligned}
$$

\begin{tabular}{|l|c|c|c|c|c|c|c|}
\hline Ticker & $\beta_{\text {out }}$ & $\sigma_{\text {in }}^{2}$ & $\sigma_{\text {out }}^{2}$ & $\kappa$ & Likelihood & \# Obs. out & LST-F \\
\hline \multicolumn{7}{|l|}{} \\
ARGENTINA \\
\hline BFR & $-0.371(.03)$ & $1.169(.03)$ & $2.283(.06)$ & 0.84 & 2889.4 & $711(46 \%)$ & $19.18(0.000)$ \\
\hline BRS & $-0.489(.04)$ & $1.190(.05)$ & $1.611(.06)$ & 0.69 & 1095.9 & $348(56 \%)$ & $8.195(0.000)$ \\
\hline YPF & $-0.427(.03)$ & $1.681(.04)$ & $3.177(.09)$ & 1.63 & 3548.1 & $548(33 \%)$ & $13.40(0.000)$ \\
\hline TAR & $-0.419(.04)$ & $1.457(.03)$ & $3.869(.13)$ & 1.59 & 3042.3 & $425(29 \%)$ & $22.05(0.000)$ \\
\hline TEO & $-0.438(.04)$ & $0.958(.03)$ & $1.400(.09)$ & 0.66 & 2087.6 & $639(48 \%)$ & $16.44(0.000)$ \\
\hline TGS & $-0.370(.03)$ & $1.589(.04)$ & $2.231(.07)$ & 1.41 & 2675.3 & $486(38 \%)$ & $18.31(0.000)$ \\
\hline \multicolumn{7}{|l|}{} \\
CHILE \\
\hline CU & $-0.343(.03)$ & $1.326(.04)$ & $1.501(.05)$ & 0.82 & 1758.1 & $530(53 \%)$ & $6.82(0.000)$ \\
\hline VCO & $-0.238(.04)$ & $1.73(.05)$ & $2.37(.10)$ & 1.98 & 1916.9 & $240(26 \%)$ & $5.47(0.000)$ \\
\hline CGW & $-0.244(.05)$ & $1.606(.04)$ & $2.650(.13)$ & 1.76 & 1849.5 & $225(24 \%)$ & $8.44(0.000)$ \\
\hline CTC & $-0.269(.03)$ & $1.062(.02)$ & $1.612(.04)$ & 0.87 & 3439.9 & $765(36 \%)$ & $9.61(0.000)$ \\
\hline AED & $-0.332(.05)$ & $1.530(.05)$ & $3.398(.15)$ & 1.47 & 1645.1 & $233(29 \%)$ & $14.72(0.000)$ \\
\hline EOC & $-0.334(.04)$ & $1.040(.03)$ & $1.597(.07)$ & 1.31 & 1758.1 & $272(24 \%)$ & $14.67(0.000)$ \\
\hline ENI & $-0.359(.04)$ & $1.124(.02)$ & $1.692(.07)$ & 1.40 & 2142.9 & $286(22 \%)$ & $9.61(0.000)$ \\
\hline LBC & $-0.340(.04)$ & $1.657(.04)$ & $3.190(.11)$ & 1.99 & 2266.7 & $268(24 \%)$ & $8.17(0.000)$ \\
\hline MAD & $-0.310(.03)$ & $1.716(.04)$ & $2.356(.07)$ & 1.70 & 2679.0 & $355(28 \%)$ & $19.46(0.000)$ \\
\hline MYS & $-0.310(.03)$ & $1.716(.04)$ & $2.356(.12)$ & 1.46 & 2757.6 & $525(40 \%)$ & $13.86(0.000)$ \\
\hline PVD & $-0.303(.05)$ & $1.578(.04)$ & $2.697(.12)$ & 1.74 & 1794.4 & $253(28 \%)$ & $14.12(0.000)$ \\
\hline BSB & $-0.303(.04)$ & $1.613(.05)$ & $2.654(.09)$ & 1.02 & 1988.8 & $456(49 \%)$ & $10.83(0.000)$ \\
\hline SQM & $-0.312(.03)$ & $1.108(.03)$ & $1.491(.04)$ & 0.90 & 2704.8 & $645(39 \%)$ & $13.08(0.000)$ \\
\hline ISA & $-0.313(.05)$ & $1.771(.05)$ & $3.450(.12)$ & 0.87 & 1690.3 & $206(26 \%)$ & $29.28(0.000)$ \\
\hline
\end{tabular}

Notes:

\# Obs. out: Number of observations outside the threshold.

LST-F: Lukkonnen, Saikkonen, and Terarsvirta's (1988) nonlinear F-test (p-value in parenthesis). 
TABLE 6. ARBITRAGE ACTIVITIES FOR CHILEAN FIRMS

This table summarizes the activities involved in arbitrage operations for Chilean firms. Transaction costs vary according to the agent performing arbitrage and the time period.

\begin{tabular}{|c|c|c|c|}
\hline \multicolumn{4}{|c|}{ USD PRICE OF LOCAL SHARE LOWER THAN ADR PRICE } \\
\hline & $\begin{array}{c}\text { ACTION } \\
\end{array}$ & TIME & TYPE OF TRANSACTION COST \\
\hline 1 & $\begin{array}{l}\text { Inflow of dollars into Chile and conversion } \\
\text { into CLP (approval by Central Bank) }\end{array}$ & up to $\mathrm{T}+7$ & $1 / 2$ spread + commission at FX market \\
\hline 2 & Buy shares at local exchange & $\mathrm{T}+2$ & $1 / 2$ spread + commission at local exchange \\
\hline 3 & Convert shares into ADRs & $?$ & fee to custodian bank \\
\hline 4 & Sell ADRs at NYSE & $\mathrm{T}+2 ?$ & $1 / 2$ spread + commission at NYSE \\
\hline \multicolumn{4}{|c|}{ ADR PRICE LOWER THAN USD PRICE OF LOCAL SHARE } \\
\hline & ACTION & TIME & TYPE OF TRANSACTION COST \\
\hline 1 & Buy NYSE ADR & $\mathrm{T}+2$ & $1 / 2$ spread + commission at NYSE \\
\hline 2 & Convert ADR into shares & & fee to custodian bank \\
\hline 3 & Sell shares at local exchange & $\mathrm{T}+2$ & $1 / 2$ spread + commission at local exchange \\
\hline 4 & $\begin{array}{l}\text { Convert CLP into USD and dollar outflow } \\
\text { (requires Central Bank's approval) }\end{array}$ & $\begin{array}{l}\text { up to } \\
\mathrm{T}+7\end{array}$ & $1 / 2$ spread + commission at FX market $(1 \%)$ \\
\hline
\end{tabular}

TABLE 7. CHRONOLOGY OF MAIN CHANGES IN CHILEAN CAPITAL CONTROLS

\begin{tabular}{|c|c|}
\hline 1991 June & $\begin{array}{ll} & \text { Unremunerated reserve requirement (URR) of } 20 \% \text { on foreign loans } \\
\text { - } & \text { Minimum holding period of between } 3 \text { and } 12 \text { months on foreign loans } \\
\end{array}$ \\
\hline \multicolumn{2}{|r|}{ 2 } \\
\hline January & - $\quad$ URR is extended to local deposits denominated in a foreign currency \\
\hline May & $\begin{array}{l}\text { - Minimum holding period of one year for all types of foreign investment except } \\
\text { ADRs }\end{array}$ \\
\hline August & - URR is increased to $30 \%$ and extended to all types of foreign investment \\
\hline \multicolumn{2}{|r|}{ 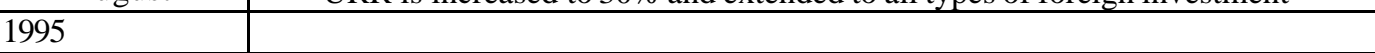 } \\
\hline July & - URR is extended to secondary ADRs \\
\hline December & - Foreign loans used abroad are exempted from the URR \\
\hline $\begin{array}{l}1996 \\
\text { December }\end{array}$ & $\begin{array}{l}\text { - Foreign loans for amounts smaller than USD200,000 are exempted from URR } \\
\text { (maximu m of USD500,000 per year) }\end{array}$ \\
\hline 1997 March & $\begin{array}{l}\text { - Foreign loans for amounts smaller than USD100,000 are exempted from URR } \\
\text { (maximum of USD100,00 per year) }\end{array}$ \\
\hline 1998 & \\
\hline June & URR is reduced to $10 \%$ \\
\hline August & - $\quad$ URR for secondary ADRs is eliminated \\
\hline September & - $\quad$ URR is reduced to $0 \%$ (not eliminated) \\
\hline 2000 May & - Minimum holding period for foreign investments is eliminated \\
\hline
\end{tabular}


TABLE 8. ESTIMATION OF TRANSACTION COSTS (Subsamples)

This table estimates the transaction costs of opening opposite positions in the locally traded shares and their ADRs, based on the (3.1) and (3.2) model:

$$
\begin{aligned}
& \mathrm{y}_{\mathrm{t}}=\alpha_{\text {out }}+\beta_{\text {out }} \mathrm{y}_{\mathrm{t}-1}+\mathrm{e}_{\text {out }, \mathrm{t}}, \quad \text { if }\left|\mathrm{y}_{\mathrm{t}-1}\right|>\kappa \\
& \mathrm{y}_{\mathrm{t}}=\alpha_{\text {in }}+\beta_{\text {in }} \mathrm{y}_{\mathrm{t}-1}+\mathrm{e}_{\text {in }, \mathrm{t}}, \quad \text { if }\left|\mathrm{y}_{\mathrm{t}-1}\right|=\kappa \\
& \mathrm{y}_{\mathrm{t}}=\mathrm{r}_{\mathrm{J}, \mathrm{t}}-\mathrm{r}_{\mathrm{US}, \mathrm{t}} \\
& \mathrm{e}_{\text {out }, \mathrm{t}} \sim \mathrm{N}\left(0, \sigma_{\text {out }}\right), \mathrm{e}_{\mathrm{in}, \mathrm{t}} \sim \mathrm{N}\left(0, \sigma^{2}{ }_{\text {in }}\right) . \\
& \mathrm{J}=\text { Argentina, Chile }
\end{aligned}
$$

\begin{tabular}{|c|c|c|c|c|}
\hline & \multicolumn{2}{|c|}{ Before September 1998 } & \multicolumn{2}{l|}{ After September 1998 } \\
\hline Ticker & $\beta_{\text {out }}$ & $\kappa$ & $\beta_{\text {out }}$ & $\kappa$ \\
\hline \multicolumn{5}{|l|}{ Argentina } \\
\hline BFR & $-0.449(.04)$ & 1.14 & $-0.482(.04)$ & 1.17 \\
\hline BRS & $-0.578(.05)$ & 2.25 & $-0.650(.05)$ & 1.24 \\
\hline IRS & $-0.471(.07)$ & 1.78 & $-0.291(.05)$ & 1.39 \\
\hline MGS & $-0.430(.04)$ & 1.30 & $-0.344(.04)$ & 1.40 \\
\hline YPF & $-0.693(.04)$ & 1.17 & $-0.462(.05)$ & 1.12 \\
\hline TAR & $-0.487(.03)$ & 0.60 & $-0.258(.05)$ & 0.83 \\
\hline TEO & $-0.561(.05)$ & 1.41 & $-0.359(.07)$ & 1.49 \\
\hline TGS & $-0.365(.04)$ & 0.99 & $-0.511(.05)$ & 1.88 \\
\hline Average & $\mathbf{- 0 . 5 0 4}$ & $\mathbf{1 . 3 3 0}$ & $\mathbf{- 0 . 4 2 0}$ & $\mathbf{1 . 3 1 5}$ \\
\hline \multicolumn{5}{|l|}{} \\
Chile & \multicolumn{5}{|l|}{} \\
\hline CU & $-0.331(.03)$ & 1.32 & $-0.339(.04)$ & 2.03 \\
\hline VCO & $-0.317(.04)$ & 2.01 & $-0.247(.04)$ & 1.03 \\
\hline CGW & $-0.268(.05)$ & 1.92 & $-0.140(.04)$ & 0.71 \\
\hline CTC & $-0.455(.03)$ & 0.90 & $-0.427(.05)$ & 0.62 \\
\hline AED & $-0.319(.05)$ & 1.40 & $-0.296(.07)$ & 2.88 \\
\hline EOC & $-0.394(.04)$ & 0.80 & $-0.212(.06)$ & 1.44 \\
\hline ENI & $-0.476(.04)$ & 0.73 & $-0.394(.05)$ & 0.93 \\
\hline LBC & $-0.533(.05)$ & 2.51 & $-0.521(.11)$ & 2.51 \\
\hline MAD & $-0.429(.04)$ & 3.12 & $-0.339(.06)$ & 3.24 \\
\hline MYS & $-0.406(.04)$ & 1.54 & $-0.216(.07)$ & 3.11 \\
\hline PVD & $-0.299(.06)$ & 2.75 & $-0.235(.04)$ & 1.00 \\
\hline BSB & $-0.315(.04)$ & 1.31 & $-0.227(.05)$ & 1.72 \\
\hline SQM & $-0.419(.03)$ & 0.85 & $-0.420(.04)$ & 0.61 \\
\hline ISA & $-0.374(.06)$ & 1.78 & $-0.199(.15)$ & 1.20 \\
\hline Average & $\mathbf{- 0 . 3 8 1}$ & $\mathbf{1 . 6 3 9}$ & $\mathbf{- 0 . 3 0 1}$ & $\mathbf{1 . 6 4 5}$ \\
\hline
\end{tabular}

Notes:

\# Obs. out: Number of observations outside the threshold.

*: Higher TAR likelihood than the single-day TAR model. 


\section{TABLE 9. TRANSACTION COSTS AND VOLUME}

This Table estimates the cross-sectional regression -see equation (5):

$$
\kappa_{i}=\alpha_{0}+\alpha_{1} D_{i}+\alpha_{2} Z_{i}+\varepsilon_{i},
$$

where $\kappa_{\mathrm{i}}$ represents the transaction costs estimated in Table $5, \mathrm{Z}_{\mathrm{i}}$ represents a trading liquidity measure (ADR Volume, in thousands, or number of days with non-zero trading volume relative to total trading days. trading days as a percentage of total days), and $\mathrm{D}_{\mathrm{i}}$ is a dummy variable defined as:

$$
\begin{aligned}
\mathrm{D}_{\mathrm{i}} & =1 \text { if } \mathrm{i}=\text { Chile } \\
& =0 \text { if } \mathrm{i}=\text { Argentina }
\end{aligned}
$$

\begin{tabular}{|l|c|c|}
\hline Variable & $\kappa$ & $\kappa$ \\
\hline Constant & 1.7717 & 7.1140 \\
& $(0.291)^{*}$ & $(1.808)^{*}$ \\
\hline Country Dummy & 0.0615 & 0.2774 \\
& $(0.301)$ & $(0.235)$ \\
\hline Volume & -0.0015 & \\
\hline Trading Days & $(0.0008)^{* *}$ & -0.0597 \\
& & $(0.019)^{*}$ \\
\hline & & .390 \\
\hline
\end{tabular}

Notes: *:significant at the $5 \%$ level. 